\title{
Nitrogen load and irradiance affect morphology, photosynthesis and growth of Caulerpa prolifera (Bryopsidales: Chlorophyta)
}

\author{
Erik-jan Malta ${ }^{1,2, *}$, Daniela G. Ferreira ${ }^{1,3}$, Juan J. Vergara ${ }^{1}{ }^{\text {, J. Lucas Pérez-Lloréns }}{ }^{1}$ \\ ${ }^{1}$ Departamento de Biología, Área de Ecología, Facultad de Ciencias del Mar y Ambientales, Universidad de Cádiz, \\ 11510 Puerto Real (Cádiz), Spain \\ ${ }^{2}$ Present address: ALGAE-Marine Plant Ecology Research Group, Centre of Marine Sciences, Universidade do Algarve, \\ Campus de Gambelas, 8005-139 Faro, Portugal \\ ${ }^{3}$ Present address: Department of Biology, University of the Azores, Rua São Gonçalo, 9504-539 Ponta Delgada, Portugal
}

\begin{abstract}
The effect of nitrogen (N) load and irradiance on morphology, growth and photosynthetic performance was studied in the green macroalga Caulerpa prolifera (Forsskål) J. V. Lamouroux from the Gulf of Cádiz (south Spain). Constant growth rates were obtained for thalli growing at different $\mathrm{N}$ loads, which could be fitted to tissue $\mathrm{N}$ using the Droop equation, rendering a maximum growth rate of $0.09 \mathrm{~d}^{-1}$, a minimum tissue $\mathrm{N}$ level of $1.71 \%$ dry weight (DW) and a critical tissue $\mathrm{N}$ of $5.2 \%$ DW. N limitation had no effects on $F_{\mathrm{v}} / F_{\mathrm{m}}$ (maximum quantum yield of chlorophyll $a$ fluorescence). Stolon production was significantly highest at low $\mathrm{N}$ loads; a reverse trend was observed for assimilator production. In a second experiment, algae were subjected to combinations of high and low N loads (HN and LN) and irradiance (HL and LL) levels. Highest growth rates were observed in the HNLL treatment, whereas the reverse combination rendered the lowest growth rate. High irradiance and high $\mathrm{N}$ load both led to increased biomass allocation to assimilators; at low $\mathrm{N}$, the bulk of the biomass ( $>75 \%$ in the HLLN treatment) was allocated to the stolons. HN had a positive effect on $F_{\mathrm{v}} / F_{\mathrm{m}}$, and HL had a negative effect. HL algae had a higher capacity for non-photochemical quenching. Despite its prolific nature, C. prolifera should be characterised as a slow-growing, but highly nitrophilic alga which has the capacity to forage for nutrients by allocating biomass to the stolons.
\end{abstract}

KEY WORDS: Caulerpa prolifera · Clonal growth · Morphology · Nitrogen foraging · Growth rate · Photosynthesis Resale or republication not permitted without written consent of the publisher

\section{INTRODUCTION}

Many higher plant species exhibit an architecture of clonal growth, i.e. a plant (genet) consists of units (ramets) which are repeated during growth. Ramets are interconnected through horizontal rhizomes and are further composed of a set of leaves (the shoot) and a root system. This clonal architecture has significant consequences with respect to life-history traits, competition, etc. (de Kroon \& van Groenendaal 1997). Terrestrial plants can use their clonal structure to most efficiently locate and explore soil nutrient micropatches (Oborny \& Cain 1997). By investing in new ramet pro- duction or, alternatively, in rhizome expansion, clonal plants are able to deal with adverse conditions and can rapidly colonise a new environment.

Seagrasses all share this architecture of clonal growth (Hemminga \& Duarte 2000). An important number of seaweeds likewise possess a clonal plant morphology, although its potential ecological consequences are rarely recognised and remain largely unexplored (Collado-Vides 2002a, Santelices 2004). With respect to resource acquisition, clonal growth appears to be particularly effective in a heterogeneous environment. As it is generally assumed that algae assimilate the majority of their nutrient requirements 
from the water column and are, hence, homogeneously distributed, the importance of clonal growth for resource acquisition seems less obvious. However, there is increasing evidence that a number of seaweeds can utilise detritus or sediment nutrient sources (Williams 1984, Larned 1998). Considering this, a clonal growth strategy might very well be feasible for seaweeds as well. Indeed, for a number of Caulerpa species, various authors have made implicit (Ceccherelli \& Cinelli 1997) and explicit (Collado-Vides \& Robledo 1999, Collado-Vides 2002b, Chisholm \& Moulin 2003) suggestions that foraging might occur. However, experimental data on this subject are missing thus far (Collado-Vides 2002a, Santelices 2004).

The green algal genus Caulerpa J. V. Lamouroux (Bryopsidales: Chlorophyta) is a well-known inhabitant of (sub)tropical seas. It is a coenocyte, i.e. each individual consists of 1 giant (up to several decimetres in length), multinucleate cell. The form of the individuals is supported and maintained by numerous ingrowths of cell-wall material, the trabeculae (Jacobs 1994). Although great interspecific morphological variability exists, all species follow a common architectural scheme, consisting of a creeping stolon bearing various erect assimilators and rhizophores with rhizoid clusters (Collado-Vides 2002a, de Senerpont Domis et al. 2003). The rhizoids do not only function as a holdfast, but are also involved in nutrient uptake from the sediment (Williams 1984, Chisholm et al. 1996). In this respect the rhizoids are analogous to the roots of vascular plants, whereas the stolons and the assimilators can be considered analogous to the rhizomes and the shoots of vascular plants.

Caulerpa prolifera is the only native Caulerpa species in continental Europe, occurring in the Mediterranean and the adjacent part of the Atlantic Ocean (Gulf of Cádiz). Additionally, C. racemosa and C. taxifolia have invaded the Mediterranean, causing a threat to the rich biodiversity of Mediterranean seagrass and seaweed stands (Meinesz et al. 2001, Piazzi et al. 2001). The 3 species form extensive beds and play an important role in ecosystem structure and functioning (Terrados \& Ros 1991, Sánchez-Moyano et al. 2001). Despite this, data on Caulerpa nutritional ecology and ecophysiology are scarce and mainly related to nutrient uptake from the sediments (Williams 1984, Chisholm et al. 1996, Chisholm \& Moulin 2003). Virtually nothing is known about the relation between nitrogen content and growth or the effect of nutrient loads on photosynthesis and algal architecture. This is ever more important given the recent debate on whether the invasive Caulerpa species form a higher risk in more eutrophic environments (Meinesz et al. 2001, Jaubert et al. 2003). The present paper was aimed to fill this gap by reporting the results of 2 experiments with C. prolifera from the Bay of Cádiz (SW Spain) with the objectives (1) to test the hypothesis that the alga follows the strategy of clonally growing plants with respect to resource acquisition, (2) to determine the relationship between nitrogen content and growth rate and (3) to detect the effects of nitrogen availability and irradiance on photosynthetic performance.

\section{MATERIALS AND METHODS}

Algal collection and cultivation. For the first experiment, attached individuals of Caulerpa prolifera (Forsskål) J. V. Lamouroux were collected from the mouth of the Río San Pedro tidal inlet near Puerto Real, southwest Spain $\left(36^{\circ} 31^{\prime} \mathrm{N}, 6^{\circ} 14^{\prime} \mathrm{E}\right)$, in October 2001. The algae were cultured in aquaria filled with filtered (Whatman GF/C), nutrient-poor oceanic water at ambient temperatures $\left(20\right.$ to $\left.23^{\circ} \mathrm{C}\right)$ for $3 \mathrm{wk}$, in order to induce nutrient starvation. Light was provided in a $14 \mathrm{~h}$ light:10 h dark cycle by a combination of a white fluorescent tube (Narva daylight, $30 \mathrm{~W}$ ) and a red fluorescent tube (Sylvania Gro-Lux, $30 \mathrm{~W}$ ), resulting in a total underwater irradiance of $100 \mu \mathrm{mol}$ photons $\mathrm{m}^{-2}$ $\mathrm{s}^{-1}$. For the second experiment, algae were collected from the same site in June 2003. As storms had 'uprooted' the thalli, loosely floating individuals were collected. The experiment was started directly on the day of collection: 15 thalli, collected on the same date, were used to determine the relations between morphometry (stolon and assimilator length) and fresh (FW) and dry weight (DW).

Experimental set-up. Effects of nitrogen load on growth, photosynthesis and morphology: Algae were carefully divided in experimental units, each consisting of a stolon bearing 2 assimilators and a number of rhizoid clusters. The units were carefully blotted dry between 4 layers of tissue, weighed and their stolon length was recorded. At the beginning of the experiment, the units were divided into 8 Erlenmeyer flasks, leaving 2 units per beaker. The plants were colourmarked using a piece of thread. The Erlenmeyer flasks were filled with 11 of artificial seawater ( $\mathrm{S}=35 \mathrm{psu})$ prepared from a sea salt mixture (hw Marinemix professional, Wiegandt, Germany). Salinity was checked using a hand refractometer (Atago). The Erlenmeyer flasks were placed in a tank filled with freshwater, which was connected to a thermostatic waterbath kept at $23^{\circ} \mathrm{C}$. Light was provided by Philips TL20W/54RS fluorescent tubes, at an intensity of $150 \mu \mathrm{mol}$ photons $\mathrm{m}^{-2} \mathrm{~s}^{-1}$ under a $16 \mathrm{~h}$ light:8 h dark cycle. Light intensity was measured with a LI 193-SA (LiCor) quantum meter mounted with a $4 \pi$ PAR (400 to $700 \mathrm{~nm}$ ) sensor. Nutrients (nitrogen and phosphate) were added from a stock solution containing $100 \mathrm{mM} \mathrm{NH}_{4} \mathrm{Cl}$ and $4 \mathrm{mM}$ 
$\mathrm{NaH}_{2} \mathrm{PO}_{4} \cdot \mathrm{H}_{2} \mathrm{O}$. By adjusting the addition volume, a range of 8 initial nutrient concentrations was obtained, which were converted to daily loads per gram fresh weight of algae (Table 1). Every $2 \mathrm{~d}$ all units were collected, cleaned of epiphytes (if necessary), carefully blotted dry between tissue, weighed and replaced into clean Erlenmeyer flasks with fresh medium. The addition volume was adapted to the new fresh weight in such a way that the nutrient load for each treatment was kept constant during the experiment. During the last $2 \mathrm{wk}$ of the experiment, $47.8 \mu \mathrm{M} \mathrm{GeO}_{2}$ was added to the medium to suppress diatom growth (Le Gall et al. 1990). The experiment lasted 32 d, after which all units were collected and weighed; the stolon length produced was recorded and the final number of assimilators was counted. Units were then split in half. One part was dried at $50^{\circ} \mathrm{C}$ for $1 \mathrm{wk}$ to determine tissue $\mathrm{C}$, $\mathrm{N}$ and $\mathrm{P}$ content. The other half was frozen in liquid nitrogen and stored at $-80^{\circ} \mathrm{C}$ for later chlorophyll analyses. The specific growth rate $(\mu)$ was determined by calculating the slope of the line through the napieran logarithms (ln) of the fresh weight during the exponential growth phase, which started after a lag phase of $10 \mathrm{~d}$ to the end of the experiment.

Algal photosynthetic performance was assessed by calculating the maximum quantum yield of photosynthesis using measurements of chla fluorescence (for details on this technique see Krause \& Weis 1991, Schreiber et al. 1999). The measurements were made with a PAM-2000 (Walz) on Days 18, 26, 28 and 29 of the experiment, at various times to detect potential diurnal dynamics or effects of medium change. Of each of the units in each treatment, 2 assimilators were chosen haphazardly, resulting in 4 readings per Erlenmeyer flask. The assimilators were mounted with a dark leaf clip (handmade or Diving-LC, Walz). A $5 \mathrm{~s}$ weak farred pulse was administered to oxidise the electron transport chain (Hanelt 1998), after which the shutters of the clips were closed. After 5 min of dark acclimatisation, the base fluorescence $F_{0}$ was measured, followed by a saturating pulse to measure $F_{\mathrm{m}}$, allowing calculation of the variable fluorescence $\left(F_{\mathrm{v}}=F_{\mathrm{m}}-F_{0}\right)$ and the maximum quantum yield of PSII (Photosystem II) $\left(F_{\mathrm{v}} / F_{\mathrm{m}}\right)$. The period of $5 \mathrm{~min}$ of dark acclimatisation after a $5 \mathrm{~s}$ far-red pulse was found to be sufficient to relax reversible non-photochemical quenching in various green macroalgal species (Hanelt 1998, Bischof et al. 2002).

Effects of irradiance and nutrient levels on growth, photosynthesis and morphology: Effects of nitrogen load, irradiance and their interaction were tested in a $2 \times 2$ fully factorial nested design (with plants nested in aquaria). Eight 30-1 aquaria were filled with a layer of approximately $2 \mathrm{~cm}$ natural sediment and 201 of artificial seawater ( $\mathrm{S}=35 \mathrm{psu}$, see above) and placed in a
Table 1. Initial nitrogen $(\mathrm{N})$ and phosphorus (P) concentrations $(\mu \mathrm{M})$ and loads (normalised to algal fresh weight, $\mu \mathrm{mol}$ nutrient $\mathrm{g} \mathrm{FW}^{-1}$ ) used in an experiment to determine the relationship between nutrient load and growth rate of Caulerpa prolifera

\begin{tabular}{|crrr|}
\hline \multirow{2}{*}{$\begin{array}{c}\text { N } \\
\text { Concentration }\end{array}$} & Load & Concentration & Load \\
\hline 1 & 1.0 & 0.25 & 0.25 \\
5 & 4.9 & 1.25 & 1.22 \\
10 & 14.0 & 2.50 & 3.50 \\
15 & 22.6 & 3.75 & 5.66 \\
20 & 31.5 & 5.00 & 7.87 \\
30 & 54.4 & 7.50 & 13.60 \\
40 & 57.0 & 10.00 & 14.26 \\
50 & 82.3 & 12.50 & 20.58 \\
\hline
\end{tabular}

cultivation chamber (D-1400-3BL, ASL). The sediment was washed thoroughly with 5 to $10 \%$ sulphuric acid and tap water to reduce organic material and nutrients. The water was gently aerated using airstones, and the temperature of the cultivation chamber was kept at $23^{\circ} \mathrm{C}$. Light was provided by Philips TLD 18W/54 fluorescent tubes under a $16 \mathrm{~h}$ light: $8 \mathrm{~h}$ dark cycle. The aquaria were subjected to a combination of either high (HL, $210 \mu \mathrm{mol}$ photons $\mathrm{m}^{-2} \mathrm{~s}^{-1}$ ) or low light (LL, $98 \mu \mathrm{mol}$ photons $\mathrm{m}^{-2} \mathrm{~s}^{-1}$ ) and high (HN, $25 \mu \mathrm{M} \mathrm{N}$ and $1 \mu \mathrm{MP}$ ) or low nutrients (LN, no additions), resulting in a total of 2 aquaria for each of the 4 treatments (HLHN, LLHN, HLLN and LLLN). Light level in the LL treatments was diminished by removing half of the fluorescent tubes. Nutrients were added from a stock solution (see above). The water was changed weekly.

Four thalli were incubated per aquarium, resulting in a total number of 8 thalli per treatment. Algal condition was determined to select the algae for the experiment. Photosynthetic performance, measured as $F_{\mathrm{v}} / F_{\mathrm{m}}$, was used as a condition parameter. Thalli, whose assimilators had a $F_{\mathrm{v}} / F_{\mathrm{m}} \geq 0.75$ were assumed to be in good condition (considering a maximum $F_{\mathrm{v}} / F_{\mathrm{m}}$ of 0.80; Häder et al. 1997, Carr \& Björk 2003) and were selected for the experiment. Selected thalli were colour-coded using a piece of thread. For each thallus, stolon length was recorded, the number of assimilators counted and their length measured. Additionally, the number of proliferations was counted and their length was measured as well. Algae were carefully blotted dry between 4 layers of tissue and weighed. The thalli were evenly distributed in each of the aquaria, gently pushing their rhizoids into the sediment. After 4 wk the experiment was terminated. Photosynthetic efficiency was assessed by $F_{\mathrm{v}} / F_{\mathrm{m}}$ as described for the first experiment. Additionally, photosynthesis (as relative electron transport rate, rETR) versus irradiance curves were determined as rapid light curves (RLCs, e.g. Carr \& 
Björk 2003). Assimilators were mounted in the dark leaf clips and were subjected to a series of 10 increasing PAR (photosynthetically active radiation) intensities, ranging from 44 to $2004 \mu \mathrm{mol}$ photons $\mathrm{m}^{-2} \mathrm{~s}^{-1}$, using the halogen lamp from the PAM as the light source. Light levels were measured with a LI 193-SA (LiCor) quantum meter mounted with a $2 \pi$ PAR (400 to $700 \mathrm{~nm}$ ) sensor. After $30 \mathrm{~s}$ of exposure time to each light intensity, the steady-state fluorescence $\left(F_{\mathrm{t}}\right)$ was measured, followed by a saturating light pulse to measure the maximum fluorescence $\left(F_{\mathrm{m}}{ }^{\prime}\right)$, and the effective quantum yield of PSII $\left[\Delta F / F_{\mathrm{m}}{ }^{\prime}=\left(F_{\mathrm{m}}{ }^{\prime}-F_{\mathrm{t}}\right) / F_{\mathrm{m}}{ }^{\prime}\right]$ was calculated. rETR was calculated as $\mathrm{rETR}=\Delta F / F_{\mathrm{m}}{ }^{\prime} \times \mathrm{PAR}$. Additionally, the coefficients for photochemical $\left(q_{\mathrm{P}}\right)$ and non-photochemical quenching $\left(q_{\mathrm{N}}\right)$ were calculated (Schreiber et al. 1999). Then, rETR was plotted versus PAR. As Caulerpa prolifera showed no signs of photoinhibition, the photosynthesis parameters maximum rETR $\left(\mathrm{rETR}_{\mathrm{m}}\right)$ and efficiency $(\alpha)$ were estimated by fitting the data to the model of Jassby \& Platt (1976) using least-squares non-linear regression. The onset of light saturation $\left(I_{\mathrm{k}}\right)$ was then calculated as $\mathrm{rETR}_{\mathrm{m}} / \alpha$. Finally, the thalli were carefully blotted dry and weighed. Relative daily growth rate (RGR) was determined as:

$$
\mathrm{RGR}=\frac{\ln \left(W_{t}-W_{0}\right)}{t}
$$

where $W_{t}$ and $W_{0}$ are final and initial fresh weight and $t$ is time $(28 \mathrm{~d})$. The same morphometric measurements were made as at the beginning of the experiment, after which plants were split in 2 for analyses as in the first experiment.

Chemical analyses. Oven-dried plants were ground using a mortar and pestle. Tissue $\mathrm{C}$ and $\mathrm{N}$ content were determined on a Perkin-Elmer $240 \mathrm{C}$ elemental $\mathrm{CHN}$ analyser. Phosphorus content was measured colourimetrically following Grasshof et al. (1983) after persulphate digestion in an autoclave. Frozen plants were ground in liquid nitrogen with a mortar and pestle. Chlorophyll $a$ and $b$ concentrations were determined after overnight extraction in acetone (Jeffrey \& Humphrey 1975).
Data analysis. Specific growth rates $(\mu)$ from the first experiment were plotted against tissue $\mathrm{N}$ content $(N)$, and the data were fitted to the Droop equation (Droop 1968), using non-linear least-squares regression:

$$
\mu=\mu_{\max }\left(1-\frac{N_{Q}}{N}\right)
$$

where $\mu_{\max }$ represents maximum specific growth rate, and $N_{\mathrm{Q}}$, the subsistence nitrogen quota (minimum $\mathrm{N}$ tissue concentration needed before growth can proceed). A third parameter estimated was $\mathrm{N}_{\mathrm{C}}$, the critical nitrogen concentration needed to sustain growth at maximum rates (sensu Pedersen \& Borum 1997). $\mathrm{N}_{\mathrm{C}}$ was estimated as the intercept between the initial slope of the Droop curve and $\mu_{\max }$ (Pedersen \& Borum 1997). For comparison, a linear regression was also performed with tissue $\mathrm{N}$ as the independent and $\mu$ as the dependent variable.

For Expt 2, differing investments in assimilators or stolons were analysed. The best way to do this is to analyse biomass partitioning for which separate weight determinations for both proportions are necessary. Given the fact that Caulerpa prolifera is coenocytic and will, therefore, lose parts of its cellular contents when damaged, probably resulting in a significant underestimation of biomass, we decided not to adopt such a destructive approach. Instead, biomass was derived from stolon and assimilator lengths, using the morphometric relations determined on plants sampled at the same time as those used in the experiment. As stolons have a cylindrical morphology and stolon thickness appeared more or less constant, stolon weight can be expected to vary linearly with stolon length. Linear regression showed that this was indeed the case, and a conversion factor was calculated by fitting a linear model with the data, forcing the intercept through zero (Table 2). For assimilators the relation between length and weight is less straightforward, as they start heart-shaped or circular and become slightly more elliptic. Hence, weight can be expected to be linearly related to the squared length in short assimilators and to length in long assimilators. A linear relationship with squared length was found up to an assimilator

Table 2. Caulerpa prolifera. Results of linear regression (intercepts forced through zero) between stolon lengths (mm) and fresh weight (FW, mg) and assimilator lengths squared $\left(\mathrm{mm}^{2}\right)$ and FW (mg) and between calculated and measured FW of algae (mg) at the beginning and end of Expt 2 (see 'Materials and methods' for explanation). Significant correlations are denoted:

\begin{tabular}{|c|c|c|c|c|}
\hline Independent & Dependent & $\mathrm{R}^{2}$ & Slope & Intercept \\
\hline Stolon length & Stolon FW & $0.78^{* * *}$ & 1.14 & 0.00 \\
\hline Assimilator length, squared & Assimilator FW & $0.85^{* * *}$ & 0.02 & 0.00 \\
\hline Calculated initial plant FW & Measured initial plant FW & $0.76^{* * *}$ & 0.70 & 0.02 \\
\hline Calculated final plant FW & Measured final plant FW & $0.88^{* * *}$ & 0.91 & -0.05 \\
\hline
\end{tabular}
${ }^{* * *} \mathrm{p}<0.001$ 
length of 60 to $70 \mathrm{~mm}$, after which marked deviations from linearity occurred. As only 4 assimilators (5.2\% of the total in initial plants) were longer than $65 \mathrm{~mm}$, this was not considered a problem, and a conversion factor was calculated for squared assimilator lengths to assimilator weight by linear regression (Table 2). For each plant, total initial and final fresh weight were then calculated as:

$$
W=\sum_{i=1}^{n}\left(1.142 \times S_{i}\right)+\sum_{j=1}^{m}\left(0.0215 \times A_{j}^{2}\right)
$$

where $W$ is weight (mg), $S$ is stolon length (mm) and $A$ is assimilator length ( $\mathrm{mm}$ ) for $n$ stolons and $m$ assimilators per plant (initial plants all had only 1 stolon, but after $4 \mathrm{wk}$ several plants had formed new stolons). A linear regression performed on calculated weights versus observed weights gave satisfactory results for both initial and final plants, validating our approach (Table 2).

The effects of nutrients and light and their interactions on RGR, plant morphology (see Table 3 for list of characters analysed), $F_{\mathrm{v}} / F_{\mathrm{m}}$ and RLC parameters $\left(\mathrm{rETR}_{\mathrm{m}}, \alpha\right.$ and $\left.I_{\mathrm{k}}\right)$ were tested using a nested 2-way ANOVA, followed by a Tukey honestly significant difference test for unequal sample sizes (Sokal \& Rohlf 1995). Data were tested for heterogeneity of variances with Bartlett's test for homogeneity prior to the ANOVA. Assimilator density (\#A/S) was log-transformed, which removed heterogeneity. No transformation could be found which removed the heterogeneity from the quantum yield data. Finally, a 2-way ANOVA was performed on the transformation that was most effective in reducing the heterogeneity of variances ( $\mathrm{p} \approx 0.01$ in Bartlett's test for homogeneity): $y^{\prime}=1 / \ln y$.

Table 3. Caulerpa prolifera. Morphological characteristics measured and their abbreviations

\begin{tabular}{|ll|}
\hline Character code & Description \\
\hline mm Stol & $\begin{array}{l}\text { Total stolon length produced per } \\
\text { plant (final - initial) } \\
\text { mm Ass }\end{array}$ \\
Total assimilator length produced \\
per plant (final - initial) \\
Number of stolons produced per \\
plant (final - initial) \\
\#Ass & $\begin{array}{l}\text { Number of assimilators produced } \\
\text { per plant (final - initial) }\end{array}$ \\
\#Prol & $\begin{array}{l}\text { Number of proliferations produced } \\
\text { per plant (final - initial) }\end{array}$ \\
\#A/S & $\begin{array}{l}\text { Number of assimilators per centi- } \\
\text { metre stolon (final plants) } \\
\text { Average assimilator length per plant } \\
\text { Avg Ass }\end{array}$ \\
(final plants only) \\
Percent of biomass allocated to \\
assimilators (final plants only)
\end{tabular}

The design was relatively large (4 treatments nested design, $\mathrm{n} \geq 6$ ), however, with unequal sample size, so the results have to be treated with care (Underwood 1997). In the 'Results' and the 'Discussion' sections, the causes of this heterogeneity are analysed. To detect the potential effects of treatments on assimilator size distribution of the entire population of assimilators (independent of the plants to which they belong), the sizes of all assimilators were pooled per treatment and tested pairwise using Kolmogorov-Smirnov 2-sample tests (Sokal \& Rohlf 1995).

\section{RESULTS}

\section{Effect of nitrogen load on growth, photosynthesis and morphology}

Thalli cultured at an initial concentration of $20 \mu \mathrm{M} \mathrm{N}$ died after 2 wk for unknown reasons. The other thalli grew well, obtaining constant growth rates after 7 to $10 \mathrm{~d}$. At higher concentrations $(\geq 30 \mu \mathrm{M} N$ initial) epiphytes (mainly small rhodophyte macrophytes) developed that were removed frequently and did not seem to impair the growth rate. The range obtained in tissue $\mathrm{N}$ concentrations after the starvation and experimental period was rather small: 2.3 to $4.7 \%$ DW. Nevertheless, a clear increase in growth rates with tissue $\mathrm{N}$ concentration was observed (Fig. 1). A linear regression returned the equation $\mu=0.018 \times N-0.0165$, with $\mathrm{R}^{2}=$ $0.69(F=29.15, \mathrm{p}<0.001, \mathrm{n}=14)$. The Droop equation gave very similar $\mathrm{R}^{2}(0.66)$ and ANOVA results $(F=$ 27.9, $\mathrm{p}<0.001, \mathrm{n}=14)$ and estimates \pm standard errors for $\mu_{\max }\left(0.09 \pm 0.01 \mathrm{~d}^{-1}\right)$ and $N_{\mathrm{Q}}(1.71 \pm 0.14 \% \mathrm{DW})$, from which $N_{\mathrm{C}}$ was calculated $(5.2 \%$ DW). Thallus morphology showed a marked response to nitrogen load. A clear tendency for an increasing number of

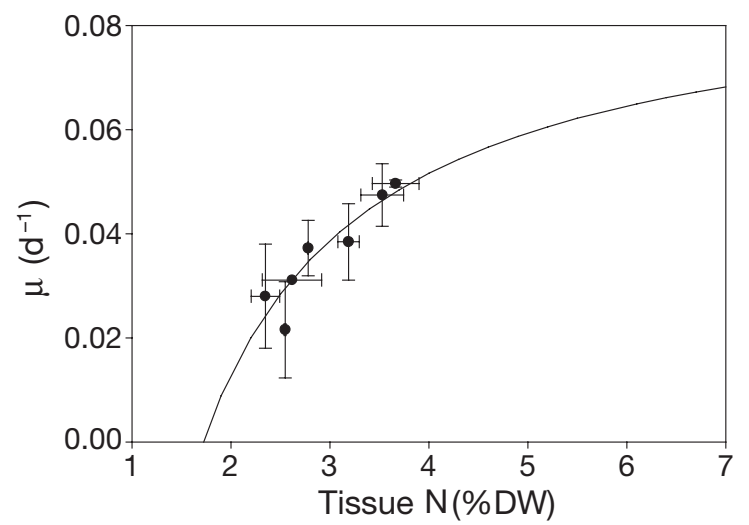

Fig. 1. Caulerpa prolifera. Relation between specific growth rate $\left(\mu, \mathrm{d}^{-1}\right)$ and tissue nitrogen content (\% dry weight) fitted to the Droop equation (continuous line). Error bars represent $\pm 1 \mathrm{SD}$ 
assimilators at higher nitrogen loads was observed, whereas stolon production showed the reverse trend (Fig. 2A). In addition, it has clearly been observed that algae at the lowest loads produced more and longer rhizoids; unfortunately, we did not quantify this. $F_{\mathrm{v}} / F_{\mathrm{m}}$ did not vary with $\mathrm{N}$ load (Fig. 2B), nor was there significant variation in quantum yield during the day or between days within treatments (data not shown).

\section{Effects of different light and nutrient levels on growth and morphology}

Most plants grew well in the aquaria, developing new assimilators and stolons already during the first week of incubation. No development of epiphytes or excessive microalgal growth occurred. There was high variation in growth rates, morphology, chlorophyll content and photosynthetic performance between plants and within treatments. Nevertheless, clear and significant responses could be observed. Tissue $\mathrm{N}$ and $\mathrm{P}$ were higher in assimilators than in stolons of initial plants (Fig. 3). Tissue N contents were highest in ini-

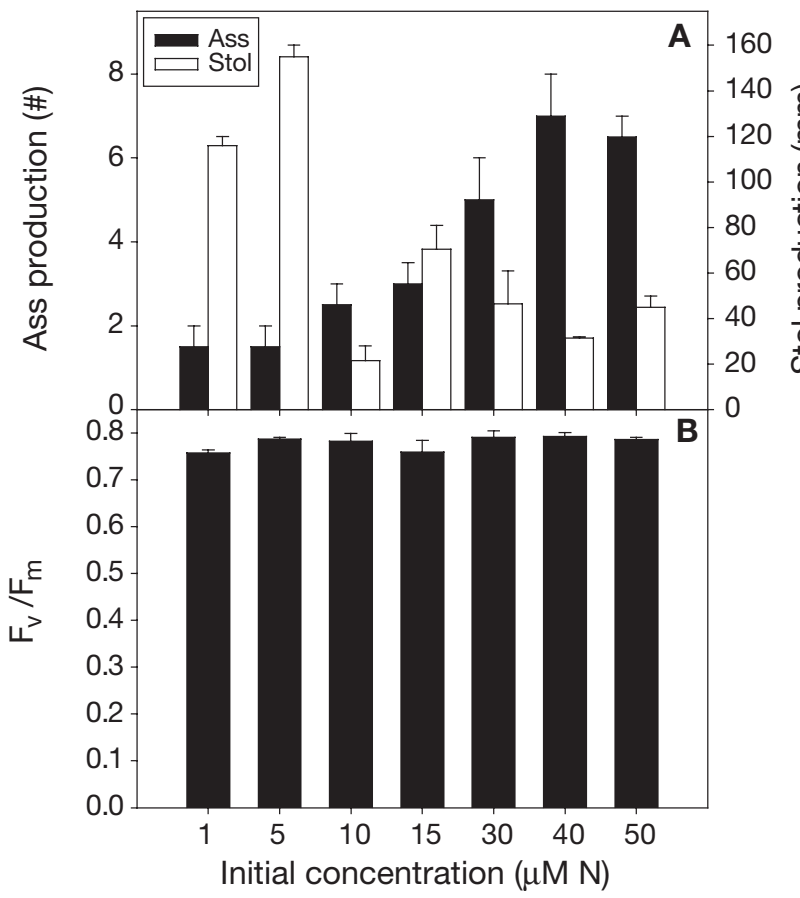

Fig. 2. Caulerpa prolifera. Effect of increasing nitrogen loads (given as initial nitrogen concentration, $\mu \mathrm{M} N$ ) on (A) morphology and (B) maximum quantum yield $\left(F_{\mathrm{v}} / F_{\mathrm{m}}\right)$ of photosynthesis. Morphological features measured were average number of assimilators (Ass) produced per plant and average stolon (Stol) length produced per thallus ( $\mathrm{mm})$. There were no significant differences between treatments $(p<0.05)$. Error bars represent $+1 \mathrm{SD}$ tial plants compared to final plants, regardless of the experimental conditions (Fig. 3). Nutrient addition resulted in significantly higher tissue $\mathrm{N}$ and $\mathrm{P}$ levels, which were not affected by the light level (Fig. 3, Table 4). Tissue C contents were slightly smaller in the LLHN treatment compared to the other treatments, the difference was insignificant however (Fig. 3, Table 4). No significant differences were observed in pigment contents (data not shown). Variation was high in both high-light treatments.

Growth rates were generally low and were significantly influenced by both light and nutrient level (Fig. 4A, Table 5), but not by their interaction. The HLLN treatment was least favourable, even showing a biomass decrease. Surprisingly, the LLHN treatment had a higher RGR than the HLHN treatment, although the difference was not significant. Most of the biomass increase (or indeed decrease) was due to changes in assimilator size and number; whereas increases in stolon length did not differ significantly between treatments (Fig. 4B,C). Number of stolons, however, was
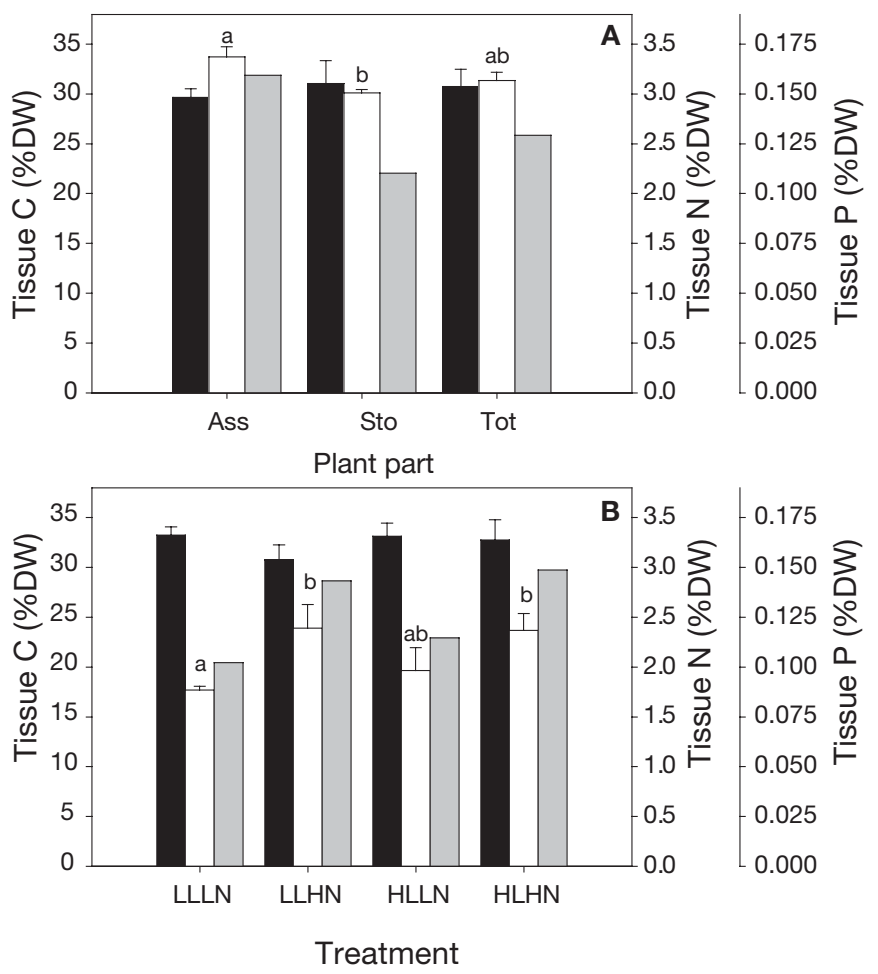

Fig. 3. Caulerpa prolifera. Tissue carbon (closed bars), nitrogen (open bars) and phosphorus (grey bars) levels (\% dry weight) in algae (A) before and (B) after being subjected to combinations of low and high irradiance (LL and HL) and low and high nutrient load (LN and HN) (\% dry weight). Nutrient levels in initial plants in assimilators (Ass), stolons (Sto) and whole plant levels (Tot). Different letters above bars indicate significant differences between treatments $(p<0.05)$. Error bars represent $\pm 1 \mathrm{SD}$ 
Table 4. Results of 2-way ANOVA on the effects of nutrient load (NUTR), irradiance (LIGHT) and their interaction $(\mathrm{N} \times \mathrm{L})$ on tissue nutrient and chlorphyll contents of Caulerpa prolifera (italics significant at $\mathrm{p}<0.05$ )

\begin{tabular}{|lllrc|}
\hline Variable & Factors & df & F-ratio & $\mathrm{p}$ \\
\hline Tissue C & NUTR & 1 & 1.867 & 0.244 \\
& LIGHT & 1 & 0.784 & 0.426 \\
& N $\times$ L & 1 & 0.990 & 0.376 \\
Tissue N & NUTR & 1 & 14.950 & 0.018 \\
& LIGHT & 1 & 0.420 & 0.552 \\
& N $\times$ L & 1 & 0.695 & 0.451 \\
Chl $a$ & NUTR & 1 & 0.177 & 0.695 \\
& LIGHT & 1 & 0.010 & 0.927 \\
Chl $b$ & N $\times$ L & 1 & 0.125 & 0.741 \\
& NUTR & 1 & 0.586 & 0.487 \\
& LIGHT & 1 & 0.027 & 0.878 \\
& N $\times$ L & 1 & 0.090 & 0.779 \\
\hline
\end{tabular}

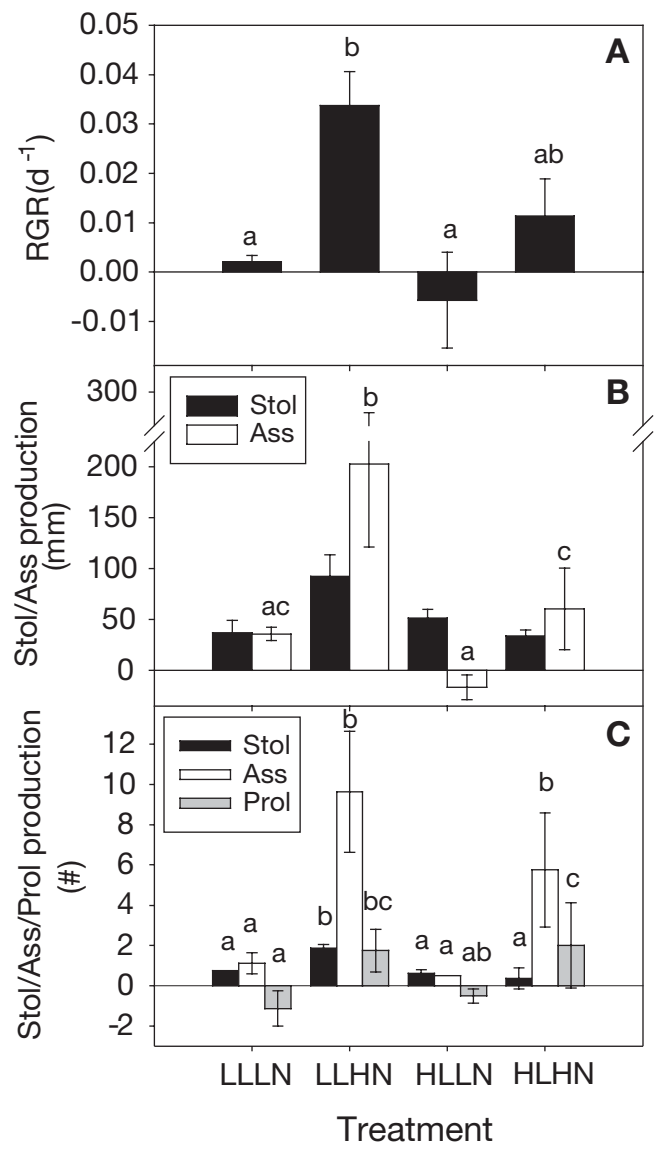

Fig. 4. Caulerpa prolifera. Results of combinations of low and high irradiance (LL and HL) and low and high nutrient load (LN and HN) on (A) relative growth rates $\left(R G R, d^{-1}\right)$, (B) average stolon (Stol) and assimilator (Ass) length produced per thallus (mm) and (C) average number of stolons, assimilators and proliferations (Prol) produced per thallus. Different letters above bars indicate significant differences between treatments $(p<0.05)$. Error bars represent \pm 1 SD significantly higher in the LLHN treatment, with no differences between the other treatments (Fig. 4C, Table 5). It can be clearly seen that the negative RGR and the decrease in total assimilator length in the HLLN treatments was due to losses in the number of proliferations (Fig. 4C). Indeed, loosely lying proliferations were found in these aquaria, which were in the process of decaying. Even higher losses of proliferations were observed in the LLLN treatment, but this was compensated by increases in assimilator size and number (Fig. 4B,C).

Both light and nitrogen levels significantly influenced plant morphology. At the beginning of the experiment, there were no significant differences between treatments in assimilator density, biomass allocation, or average assimilator size, although variation

Table 5. Results of nested 2-way ANOVA on the effects of nutrient load (NUTR), irradiance (LIGHT) and their interaction $(\mathrm{N} \times \mathrm{L})$ on growth rate and morphological charateristics of Caulerpa prolifera (italics significant at $\mathrm{p}<0.05$ )

\begin{tabular}{|c|c|c|c|c|}
\hline Variable & Factors & df & F-ratio & $\mathrm{p}$ \\
\hline \multirow[t]{4}{*}{$\mu$} & Nest & 4 & 0.593 & 0.672 \\
\hline & NUTR & 1 & 14.120 & 0.001 \\
\hline & LIGHT & 1 & 5.390 & 0.030 \\
\hline & $\mathrm{N} \times \mathrm{L}$ & 1 & 1.266 & 0.273 \\
\hline \multirow[t]{4}{*}{ mm Stol } & Nest & 4 & 0.190 & 0.941 \\
\hline & NUTR & 1 & 0.762 & 0.391 \\
\hline & LIGHT & 1 & 1.047 & 0.316 \\
\hline & $\mathrm{N} \times \mathrm{L}$ & 1 & 2.889 & 0.102 \\
\hline \multirow[t]{4}{*}{ mm Ass } & Nest & 4 & 3.443 & 0.023 \\
\hline & NUTR & 1 & 48.318 & $<0.001$ \\
\hline & LIGHT & 1 & 30.718 & $<0.001$ \\
\hline & $N \times L$ & 1 & 6.597 & 0.017 \\
\hline \multirow[t]{4}{*}{ \#Stol } & Nest & 4 & 0.943 & 0.456 \\
\hline & NUTR & 1 & 4.200 & 0.052 \\
\hline & $L I G H T$ & 1 & 14.486 & 0.001 \\
\hline & $N \times L$ & 1 & 10.371 & 0.004 \\
\hline \multirow[t]{4}{*}{ \#Ass } & Nest & 4 & 1.682 & 0.187 \\
\hline & NUTR & 1 & 36.741 & $<0.001$ \\
\hline & LIGHT & 1 & 3.935 & 0.059 \\
\hline & $\mathrm{N} \times \mathrm{L}$ & 1 & 2.053 & 0.165 \\
\hline \multirow[t]{4}{*}{ \#Prol } & Nest & 4 & 2.297 & 0.088 \\
\hline & NUTR & 1 & 20.319 & $<0.001$ \\
\hline & LIGHT & 1 & 0.538 & 0.470 \\
\hline & $\mathrm{N} \times \mathrm{L}$ & 1 & 0.099 & 0.756 \\
\hline \multirow[t]{4}{*}{$\%$ Ass } & Nest & 4 & 1.002 & 0.426 \\
\hline & NUTR & 1 & 54.033 & $<0.001$ \\
\hline & LIGHT & 1 & 29.426 & $<0.001$ \\
\hline & $\mathrm{N} \times \mathrm{L}$ & 1 & 1.466 & 0.238 \\
\hline \multirow[t]{4}{*}{ \#A/S } & Nest & 4 & 0.569 & 0.688 \\
\hline & NUTR & 1 & 39.014 & $<0.001$ \\
\hline & LIGHT & 1 & 3.936 & 0.059 \\
\hline & $\mathrm{N} \times \mathrm{L}$ & 1 & 0.645 & 0.430 \\
\hline \multirow[t]{4}{*}{ Avg Ass } & Nest & 4 & 0.210 & 0.931 \\
\hline & NUTR & 1 & 2.817 & 0.106 \\
\hline & LIGHT & 1 & 18.412 & $<0.001$ \\
\hline & $\mathrm{N} \times \mathrm{L}$ & 1 & 0.800 & 0.380 \\
\hline
\end{tabular}


was high in some cases (Fig. 5). During the experiment, assimilator density and size decreased in all treatments (Fig. 5A,C). High nutrient levels resulted in a higher density, independent of light level (Fig. 5A, Table 5). However, when biomass allocation is considered, both high light and high nutrient levels significantly had a higher proportion of the biomass allocated to assimilators independently of each other (no interaction, Table 5). The discrepancy between these 2 can be explained by the proliferations, which were higher in the high-nutrient treatments. In the HLLN treatment even more than $75 \%$ of the biomass was allocated to the stolons (Fig. 5B). Assimilator size was significantly higher at low light levels, independent of nutrients. This difference was confirmed in a comparison of the

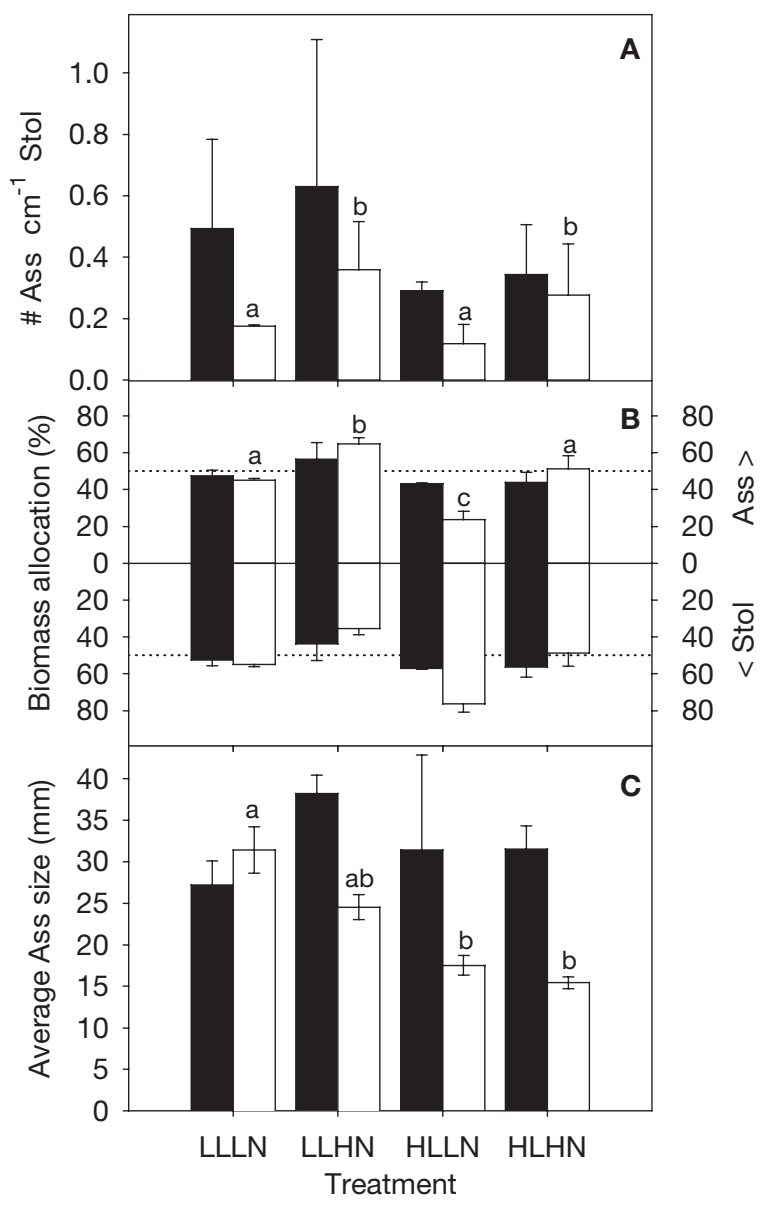

Fig. 5. Caulerpa prolifera. Results of combinations of low and high irradiance (LL and HL) and low and high nutrient load (LN and $\mathrm{HN}$ ) on (A) assimilator density per stolon (\# Ass $\mathrm{cm}^{-1}$ Stol), (B) percent biomass allocated to stolons or assimilators and $(\mathrm{C})$ average assimilator size per thallus $(\mathrm{mm})$, before (closed bars) and after (open bars) the experiment. Dotted lines in (B) indicate $50 \%$ biomass allocation. Different letters above bars indicate significant differences between treatments $(p<0.05)$. Error bars represent \pm 1 SD size distribution of the entire assimilator population, where low-light size distributions significantly differed from high-light size distributions (Table 6). Assimilators from low-light algae could be found in all size classes, except the smallest, whereas assimilators from plants grown under high light were mainly clumped in the 4 smallest size classes (Fig. 6).

$F_{\mathrm{v}} / F_{\mathrm{m}}$ was significantly affected by light and nutrients, but not by their interaction (Fig. 7, Table 7). The high-nutrient treatments had the highest efficiencies (highest in LLHN), whereas HLLN scored lowest (Fig. 7), with yields under 0.6, indicating photoinhibition. A significant effect of nesting (difference between plants within aquaria) and significant heterogeneity of variances were detected however; hence, the results have to be treated with care. Standard deviation was negatively correlated to average yield; apparently, as conditions become less optimal or more adverse for algal photosynthesis, the variation increases, both between individuals as well as between assimilators within individuals. RLCs of the plants fitted well to a production model excluding photoinhibition (>95\% of

Table 6. Kolmogorov-Smirnov 2-sample test results (p) of pairwise comparisons of combinations of high and low irradiance (HL and LL, respectively) and high and low nutrient load (HN and LN, respectively) on the assimilator size distribution of Caulerpa prolifera

\begin{tabular}{|ccccc|}
\hline & LLLN & LLHN & HLLN & HLHN \\
\hline LLLN & - & $>0.10$ & $<0.025$ & $<0.001$ \\
LLHN & & - & $<0.10$ & $<0.01$ \\
HLLN & & & & $>0.10$ \\
\hline
\end{tabular}

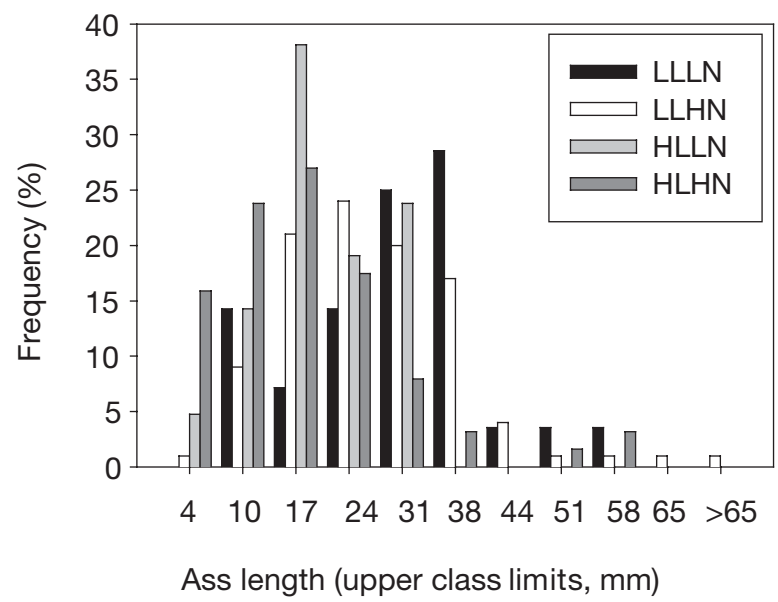

Fig. 6. Caulerpa prolifera. Frequency distribution of assimilator lengths $(\mathrm{mm})$ after being subjected to combinations of low and high irradiance (LL and HL) and low and high nutrient load (LN and HN) 


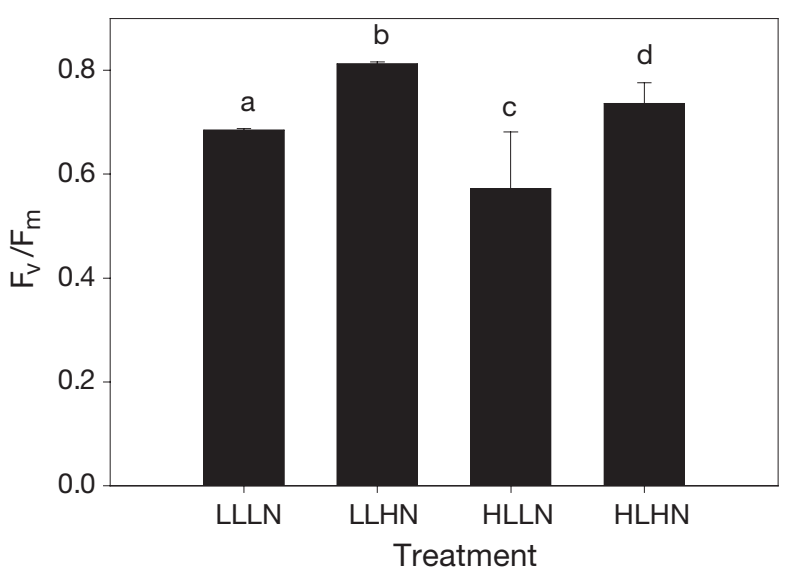

Fig. 7. Caulerpa prolifera. Results of combinations of low and high irradiance (LL and HL) and low and high nutrient load (LN and HN) on maximum quantum yield $\left(F_{\mathrm{v}} / F_{\mathrm{m}}\right)$. Different letters above bars indicate significant differences between treatments $(p<0.05)$. Error bars represent +1 SD

the variation could be explained by the model in 36 of the 38 RLCs made, RLCs not shown). The RLC parameters $\mathrm{rETR}_{\mathrm{m}}$ and $\alpha$ significantly increased with increasing nutrients, but decreased with increasing light; hence, they were highest in the LLHN algae (Tables 7 \& 8). It has to be kept in mind however that these are relative values, depending on algal light absorbance, which was unknown, but most probably different, at least between the HL and LL treatments. $I_{\mathrm{k}}$ was highest in the HN treatments and independent of light level. This parameter does not depend on absorbance.

Table 7. Results of nested 2-way ANOVA on the effects of nutrient load (NUTR), irradiance (LIGHT) and their interaction $(\mathrm{N} \times \mathrm{L})$ on maximum quantum yield of photosynthesis $\left(F_{\mathrm{v}} / F_{\mathrm{m}}\right)$ and the $P-I$ curve parameters $\mathrm{rETR}_{\max } \alpha$ and $I_{\mathrm{k}}$ of Caulerpa prolifera (italics significant at $\mathrm{p}<0.05$ )

\begin{tabular}{|llrrr|}
\hline Variable & Factors & df & F-ratio & \multicolumn{1}{c|}{$\mathrm{p}$} \\
\hline$F_{\mathrm{v}} / F_{\mathrm{m}}$ & Nest & 4 & 6.371 & 0.010 \\
& NUTR & 1 & 103.078 & $<0.001$ \\
& LIGHT & 1 & 43.964 & $<0.001$ \\
& $\mathrm{~N} \times \mathrm{L}$ & 1 & 1.625 & 0.072 \\
$\mathrm{rETR}_{\max }$ & Nest & 4 & 1.562 & 0.214 \\
& NUTR & 1 & 20.535 & $<0.001$ \\
& LIGHT & 1 & 10.695 & 0.003 \\
& N $\times \mathrm{L}$ & 1 & 1.963 & 0.173 \\
$\alpha$ & Nest & 4 & 1.482 & 0.236 \\
& NUTR & 1 & 25.037 & $<0.001$ \\
& LIGHT & 1 & 15.355 & 0.001 \\
$I_{\mathrm{k}}$ & N $\times \mathrm{L}$ & 1 & 1.413 & 0.245 \\
& Nest & 4 & 0.547 & 0.703 \\
& NUTR & 1 & 4.630 & 0.041 \\
& LIGHT & 1 & 0.380 & 0.543 \\
& N $\times \mathrm{L}$ & 1 & 0.005 & 0.942 \\
\hline
\end{tabular}

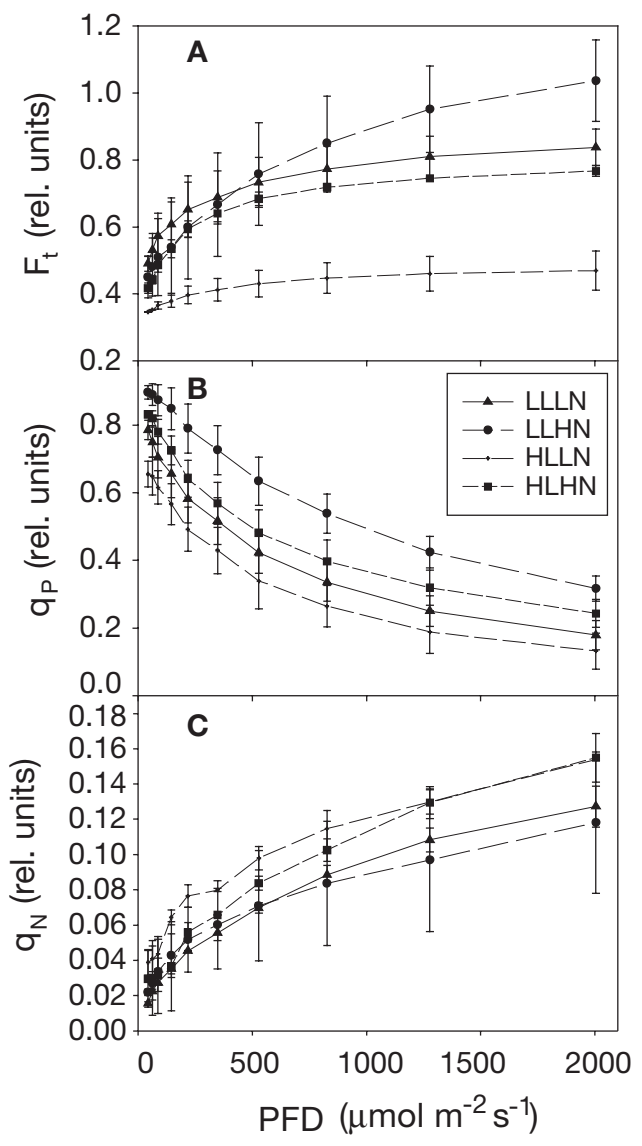

Fig. 8. Caulerpa prolifera. Results of combinations of low and high irradiance (LL and HL) and low and high nutrient load (LN and HN) on (A) steady-state fluorescence $\left(F_{\mathrm{t}}\right),(\mathrm{B})$ photochemical quenching $\left(q_{\mathrm{P}}\right)$ and $(\mathrm{C})$ non-photochemical quench$\operatorname{ing}\left(q_{\mathrm{N}}\right)$. Error bars represent $\pm 1 \mathrm{SD}$

Clear responses to treatments were observed in the steady-state fluorescence $\left(F_{\mathrm{t}}\right)$ and quenching parameters $\left(q_{\mathrm{P}}\right.$ and $\left.q_{\mathrm{N}}\right)$ (Fig. 8). Acclimatisation to the cultivation light level clearly played an important part in determining $F_{\mathrm{t}}$ and $q_{\mathrm{N}}$, as excess energy in plants grown under low light was mainly channelled away as

Table 8. Caulerpa prolifera. Average estimates $( \pm 1 \mathrm{SD})$ of $\mathrm{rETR}_{\mathrm{m}}, \alpha$ and $I_{\mathrm{k}}$ from rapid light curves fitted to the equation of Jassby \& Platt (1976) for plants subjected to 4 experimental treatments consisting of combinations of high and low irradiance (HL and LL, respectively) and high and low nutrient load (HN and LN, respectively). Different letters next to values indicate significant differences $(\mathrm{p}<0.05)$ between treatments

\begin{tabular}{|lccc|}
\hline Treatment & $\begin{array}{c}\text { rETRm } \\
\text { (rel. units) }\end{array}$ & $\begin{array}{c}\alpha \\
(\text { rel. units) }\end{array}$ & $\begin{array}{c}I_{\mathrm{k}} \\
\left(\mu \mathrm{mol} \mathrm{m} \mathrm{m}^{-2} \mathrm{~s}^{-1}\right)\end{array}$ \\
\hline LLLN & $185.5 \pm 65.2^{\mathrm{a}}$ & $0.34 \pm 0.06^{\mathrm{a}}$ & $518.7 \pm 85.9^{\mathrm{a}}$ \\
LLHN & $397.7 \pm 34.7^{\mathrm{b}}$ & $0.53 \pm 0.07^{\mathrm{b}}$ & $753.7 \pm 23.8^{\mathrm{b}}$ \\
HLLN & $118.6 \pm 16.7^{\mathrm{a}}$ & $0.25 \pm 0.04^{\mathrm{a}}$ & $461.3 \pm 19.5^{\mathrm{a}}$ \\
HLHN & $230.7 \pm 85.8^{\mathrm{a}}$ & $0.37 \pm 0.01^{\mathrm{a}}$ & $680.8 \pm 176.0^{\mathrm{b}}$ \\
\hline
\end{tabular}


$F_{\mathrm{t}}$, while in high-light plants $q_{\mathrm{N}}$ played a more important role both in high- and low-nutrient regimes (Fig. 8A,C). Photochemical quenching $\left(q_{\mathrm{P}}\right)$ followed the same pattern as the RGR, rETR and the $P-I$ curve parameters in that it was highest at all light intensities for the LLHN plants and lowest for the HLLN plants (Fig. 8B).

\section{DISCUSSION}

\section{Effect of nutrient availability on morphology}

Clonal growth strategy for terrestrial plants predicts that clonal plants acclimatise their architecture to optimal foraging provided the habitat is temporally predictable (de Kroon \& Hutchings 1995). This means that plants growing in nutrient-poor environments will allocate their resources to the development of belowground biomass, consequently resulting in a rather low shoot/root biomass ratio (de Kroon \& Hutchings 1995). Aquatic environments present a fundamental difference compared with the terrestrial environment, in that nutrients are both available in the water column and in the sediment. Hence, leaves of aquatic plants (or fronds of macroalgae) are 'multifunctional', i.e. are responsible for both photosynthesis and nutrient uptake. Although the water column is considered to be the major nutrient source for macroalgae, it has been shown that the sediment plays a much more important role as a nutrient resource than has generally been assumed (Williams 1984, Larned 1998). This means that the advantages of clonal growth with respect to nutrient acquisition also hold for aquatic plants, especially for seagrasses and macroalgae growing on sediments. Thus, at low nutrient levels, in the aquatic realm it can be expected that plants invest in roots and rhizomes or rhizoids to explore the sediment for resources. Indeed, this strategy has been reported for a number of seagrass species (Short 1983, Terrados et al. 1999).

In the present study, a strong morphological response to nutrient availability was recorded for the clonal-growing macroalga Caulerpa prolifera. Biomass allocation clearly shifted from stolons at low $\mathrm{N}$ loads to assimilators at high $\mathrm{N}$ loads, resulting in more and longer assimilators at higher loads, while development of stolons and rhizoids is stimulated in algae suffering chronic nutrient limitation. From this we conclude that C. prolifera forages and thus follows the strategy of clonally growing plants, for which experimental evidence has thus far been lacking (Collado-Vides 2002a, Santelices 2004). This is even more remarkable considering that Caulerpa is a coenocytic alga. The formation of extra assimilators and/or stolons or rhizoids is hence merely a consequence of small-scale differences in cell-wall stretching. It is known that gravity and light climate are important factors in assimilator and rhizoid formation (Collado-Vides 2002b, de Senerpont Domis et al. 2003). The present results indicate that nutrient availability also has its effect on morphogenesis. Another remarkable response is the shedding of proliferations at low nutrient concentrations. It can be hypothesised that shedding is a functional response to nutrient limitation, to promote dispersal and hence secure the survival of the genotype. This, however, remains speculative.

Clonal land and aquatic plants growing under reduced light levels generally allocate their biomass to shoots and leaves, resulting in plants with a more compact growth form (de Kroon \& Hutchings 1995). Caulerpa prolifera in this study indeed showed a biomass allocation pattern as described above. Algae grown at low light had more biomass allocated to assimilators compared to plants grown at the same nutrient level, but at a higher light level. Assimilator length was also clearly greater in low-light plants, which is in agreement with results of Collado-Vides (2002b). Growth rates, however, indicate that light was not limiting, on the contrary even, growth was highest at the low irradiance level. More experimental research, subjecting plants to a broader range of light levels, is needed to clarify whether biomass allocation in $C$. prolifera is influenced by light intensity.

\section{Caulerpa growth rates and nitrogen requirements}

Specific growth rates of Caulerpa prolifera in both experiments were low, never exceeding $0.05 \mathrm{~d}^{-1}$. We did not find reports on $\mu$ of $C$. prolifera in the literature; however, Williams et al. (1985) and Larned (1998) reported $\mu$ in 5 other Caulerpa species to range between 0.014 and $0.073 \mathrm{~d}^{-1}$. From the field biomass data of $C$. prolifera and C. taxifolia (Terrados \& Ros 1991, Meinesz et al. 1995), net maximum growth rates can be calculated to range between 0.005 and $0.017 \mathrm{~d}^{-1}$. Although these reported values cannot be compared directly, as they were recorded under different circumstances (different experiments, field data, etc.), they clearly indicate that, despite the rapid spreading of these species and the invasive behaviour of $C$. racemosa and $C$. taxifolia in the Mediterranean and other areas (Jousson et al. 2000, Schaffelke et al. 2002, Williams \& Grosholz 2002), it can be concluded that Caulerpa spp. in general are relatively slow-growing species. In this respect they are comparable to seagrasses such as Cymodocea nodosa and Zostera marina (Hemminga \& Duarte 2000) or slow-growing seaweeds (growth rates of various species listed in Fortes \& Lüning 1980, Larned 1998). 
This is in contrast to other proliferating green macroalgae such as Ulva, Enteromorpha and Cladophora species, which can have growth rates up to $0.3-0.5 \mathrm{~d}^{-1}$ (Hernández et al. 1997, Malta \& Verschuure 1997).

The low maximum growth rate predicted by the Droop equation confirms the characterisation of Caulerpa prolifera as a slow-growing alga. This estimate must be considered with some care however, as the point of saturation of growth with increasing tissue $\mathrm{N}$ content has not yet been observed and linear regression gave a similar value for $\mathrm{R}^{2}$ as the Droop model. Nevertheless, the results clearly indicate that Caulerpa is a highly nitrophilic alga, as both the $N_{\mathrm{Q}}$ and $N_{\mathrm{C}}$ values are among the highest that have been determined for macroalgae (Pedersen \& Borum 1996, Table 5.9 in Lobban \& Harrison 1997, Campbell 2001). Contrastingly, algae with similar minimum $\mathrm{N}$ contents are all fast-growing species. High tissue $\mathrm{N}$ levels in Caulerpa species (up to $12.7 \%$ DW in C. sertularioides) have been reported before (Delgado et al. 1996, Robledo \& Pelegrín 1997, Larned 1998). Caulerpa species are known to contain relatively high numbers of endosymbiotic bacteria (especially in the rhizomes, Chisholm et al. 1996, Meusnier et al. 2001), and marine bacteria generally have high nitrogen levels and C:N ratios equal to or even lower than the Redfield ratio for phytoplankton (Fukuda et al. 1998). Chisholm et al. (1996) estimated C. taxifolia to contain $10^{4}$ to $10^{5}$ bacteria $\mathrm{mm}^{-3}$. Assuming a $\mathrm{N}$ content of $5.8 \mathrm{fg} \mathrm{cell}^{-1}$ (average for coastal bacteria, Fukuda et al. 1998) and a specific stolon dry weight of $6.34 \times 10^{-5} \mathrm{~g} \mathrm{~mm}^{-3}$ stolon (taken from our own data on C. prolifera), the amount of bacterial $\mathrm{N}$ can roughly be estimated to range between $9.15 \times 10^{-5}$ and $9.15 \times 10^{-4} \%$ of Caulerpa dry weight. This means that, at the most, $0.05 \%$ of the measured $\mathrm{N}$ in Caulerpa is in fact bacterial $\mathrm{N}$, a negligible amount.

The extensive secondary metabolism of Caulerpa species may be a better explanation of their high $\mathrm{N}$ requirements. Caulerpa species contain high levels of terpenes (up to 3.6-4.2\% DW, Jung et al. 2002), which are thought to function as herbivore repellents and natural antibiotics (Paul \& Fenical 1986, Jung et al. 2002). When wounded or attacked, a very rapid enzyme-mediated conversion of these terpenes occurs, enhancing the chemical protection of the alga even more (Jung et al. 2002). Caulerpenyne and the conversion products do not contain nitrogen; however, this fast response implies that the enzymes needed for the transformation should be present (and active) in relatively high amounts. Shanmugam et al. (2001) indeed have reported high protein levels in various Caulerpa species; however, Robledo \& Pelegrín (1997) found relatively low amounts in C. racemosa. Besides terpenes, Caulerpa spp. also possess secondary metabolites that do contain nitrogen (see e.g. Faulkner 1999, Levi \& Freidlander 2004). However, other explanations for the high nitrogen requirements of Caulerpa spp. may exist, and further studies on this aspect are needed.

Despite the high $\mathrm{N}$ requirements, many studies have demonstrated the lack of in situ nutrient limitation in Caulerpa spp., even in nutrient-poor environments (Delgado et al. 1996, Ceccherelli \& Sechi 2002). The algae have high nutrient-uptake capacities from the sediment through their rhizoids (Williams 1984, Chisholm et al. 1996); according to Williams et al. (1985) sediment uptake even accounts for the total $\mathrm{N}$ requirement. Additionally, studies on C. taxifolia-inhabited sediments show a stimulation of the breakdown of organic material and of bacterial nitrogen fixation (Chisholm \& Moulin 2003), thereby increasing the sediment nutrient pools. In fact, in the cases where nutrient limitation was reported (Larned 1998, for tropical C. sertularioides and C. racemosa, and Terrados \& Ros 1991, for Mediterranean C. prolifera), this was demonstrated in bioassays with detached plants, which were hence deprived of their sediment nutrient source; this was also the case in the first experiment reported here. Considering their low tissue $\mathrm{N}$ levels, plants in the second experiment were also N-limited. This limitation was most severe in the low-nitrogen treatments and can be held responsible for the difference in growth rates between the low- and high-nutrient treatments. These plants were grown on natural sediments; however, the vigorous washing with sulphuric acid and tap water prior to the experiment successfully removed organic material and nutrients. This is in agreement with the hypothesis put forward by Terrados \& Ros (1991) that C. prolifera may be limited in sandy sediments that contain less organic material. Tissue $\mathrm{N}$ in $C$. prolifera from our field site varied between 2.8 and $4.0 \%$ DW, depending on season, and were always higher than tissue $\mathrm{N}$ levels in the seagrasses Cymodocea nodosa and Zostera marina collected from the same site at the same time (present paper and authors' unpubl. data). Considering the high critical level, $C$. prolifera at our sites was always slightly N-limited. In conclusion it can be said that, considering the low growth rate, high uptake capacity of the rhizoids and the capacity demonstrated in this paper to forage for nutrients, severe nutrient limitation is very unlikely to occur in Caulerpa, even in nutrient-poor waters, except on sediments containing little organic material.

\section{Effects of irradiance and nitrogen levels on photosynthesis}

Photosynthetic efficiency expressed as $F_{\mathrm{v}} / F_{\mathrm{m}}$ was found to decrease under nutrient limitation stress in 
many phytoplankton species (Geider et al. 1993, Yentsch et al. 2004). This was debated, however, by Parkhill et al. (2001), who found that $F_{\mathrm{v}} / F_{\mathrm{m}}$ is rather insensitive to nutrient-limitation stress in phytoplankton cells in the steady state, experiencing balanced growth. Under these conditions the algae were able to acclimatise to chronically low nutrient availability and to maintain high photosynthetic efficiencies. This view was supported by the results of Young \& Beardall (2003). Decreases in $F_{\mathrm{v}} / F_{\mathrm{m}}$ as a result of nutrient limitation were also found in macroalgae (Henley et al. 1991, Korb \& Gerard 2000, Gordillo et al. 2003); however, in all these studies algae were $\mathrm{N}$-starved. The results from this study show that Caulerpa prolifera can maintain a high $F_{\mathrm{v}} / F_{\mathrm{m}}$ under low, but constant, nutrient availability (nutrient limitation, Expt 1). Under nutrient starvation (Expt 2), a significant decrease in $F_{\mathrm{v}} / F_{\mathrm{m}}$ was observed. Hence, we support the conclusion of Parkhill et al. (2001) that algae can maintain a high $F_{\mathrm{v}} / F_{\mathrm{m}}$ under nutrient limitation (balanced growth), but not under nutrient starvation. The high variance in $F_{\mathrm{v}} / F_{\mathrm{m}}$ between aquaria within treatment (significant nesting effect) and between assimilators within plants in the HL treatments impairs the interpretation of the results from the second experiment. Nevertheless, it can be clearly seen that nitrogen starvation leads to a reduction in maximum quantum yield.

The difference in $q_{\mathrm{N}}$ as shown in the RLCs found between plants cultivated at low and high light intensity clearly shows the capacity of Caulerpa prolifera of acclimatising to different light climates. This heat dissipation is considered a photoprotective mechanism (Ralph 1999, Bischof et al. 2002). The high $I_{\mathrm{k}}$ found in the $\mathrm{HN}$ treatments also indicates that $C$. prolifera is well adapted to high irradiances, provided that nitrogen is not limiting. This corroborates with the findings of Terrados \& Ros (1992) and Gacia et al. (1996). Furthermore, the negative effect of nitrogen starvation is again demonstrated in the lower $q_{\mathrm{P}}$ values for the LN treatments. Despite the acclimatisation capacity of the photosystem to higher cultivation light levels, $q_{\mathrm{P}}, F_{\mathrm{v}} / F_{\mathrm{m}}$ and, ultimately, growth rates were highest in the HNLL treatment, indicating a preference for low or moderate growth irradiances. This supports the conclusion of Häder et al. (1997) that photoinhibition occurred in this alga even in its natural habitat when the sun was at high angles.

\section{Concluding remarks}

Caulerpa prolifera should be ecologically characterised as a slow-growing, nitrophilic species. Nitrogen limitation clearly stimulated stolon formation, indicating the capacity of the alga to forage for nutrients.
Further studies in which algae are cultivated on heterogeneous (with respect to nutrients) sediments, field inventories comparing algal morphology and sediment types and long-term experiments to study effects on the population are needed to check whether this morphological plasticity is indeed an adaptive feature.

Acknowledgements. We thank A. Martínez (University of Málaga) for the C:N analyses. E.-J.M. acknowledges a Marie Curie fellowship of the European Community Programme 'Energy, Environment and Sustainable Development' (Contract No. EVK3-CT-2000-50003) and a Marie Curie European Reintegration Grant (Contract No. MERG-CT-2004-006385). D.G.F. acknowledges the Regional Directorate of Youth, Employment and Vocational Training of the Autonomous Government of the Azores (DRJEFP/RAA, Portugal) and the European Union for awarding a scholarship to participate on the transnational vocational training programme Leonardo da Vinci. The study was supported by the project ECOMARINA (REN2002-0746/MAR) funded by the Spanish Ministry for Science and Technology (McyT).

\section{LITERATURE CITED}

Bischof K, Peralta G, Kräbs G, van de Poll WH, Pérez-Lloréns JL, Breeman AM (2002) Effects of solar UV-B radiation on canopy structure of Ulva communities from southern Spain. J Exp Bot 53:2411-2421

Campbell SJ (2001) Ammonium requirements of fast-growing ephemeral macroalgae in a nutrient-enriched marine embayment (Port Philip Bay, Australia). Mar Ecol Prog Ser 209:99-107

Carr H, Björk M (2003) A methodological comparison of photosynthetic oxygen evolution and estimated electron transport rate in tropical Ulva (Chlorophyta) species under different light and inorganic carbon conditions. J Phycol 39:1125-1131

Ceccherelli G, Cinelli F (1997) Short-term effects of nutrient enrichment of the sediment and interactions between the seagrass Cymodocea nodosa and the introduced green alga Caulerpa taxifolia in a Mediterranean bay. J Exp Mar Biol Ecol 217:165-177

Ceccherelli G, Sechi N (2002) Nutrient availability in the sediment and the reciprocal effects between the native seagrass Cymodocea nodosa and the introduced rhizophytic alga Caulerpa taxifolia. Hydrobiologia 474:57-66

Chisholm JRM, Moulin P (2003) Stimulation of nitrogen fixation in refractory organic sediments by Caulerpa taxifolia. Limnol Oceanogr 48:787-794

Chisholm JRM, Dauga C, Ageron E, Grimont PAD, Jaubert JM (1996) 'Roots' in mixotrophic algae. Nature 381:382

Collado-Vides L (2002a) Clonal architecture in marine macroalgae: ecological and evolutionary perspectives. Evol Ecol 15:531-545

Collado-Vides L (2002b) Morphological plasticity of Caulerpa prolifera (Caulerpales, Chlorophyta) in relation to growth form in a coral reef lagoon. Bot Mar 45:123-129

Collado-Vides L, Robledo D (1999) Morphology and photosynthesis of Caulerpa (Chloropyta) in relation to growth form. J Phycol 35:325-330

de Kroon H, Hutchings MJ (1995) Morphological plasticity in clonal plants: the foraging concept reconsidered. J Ecol 83:143-152

de Kroon H, van Groenendael J (eds) (1997) The ecology and 
evolution of clonal growth in plants. Backhuys Publishers, Leiden

Delgado O, Rodríquez-Prieto C, Gacia E, Ballesteros E (1996) Lack of severe nutrient limitation in Caulerpa taxifolia (Vahl) C. Agardh, an introduced seaweed spreading over the oligotrophic northwestern Mediterranean. Bot Mar 39: 61-67

de Senerpont Domis LN, Famà P, Bartlett AJ, Prud'homme van Reine WF, Armenta Espinosa C, Trono Jr GC (2003) Defining taxon boundaries in members of the morphologically and genetically plastic genus Caulerpa (Caulerpales, Chlorophyta). J Phycol 39:1019-1037

Droop MR (1968) Vitamine $B_{12}$ and marine ecology. IV. The kinetics of uptake, growth and inhibition in Monochrysis lutheri. J Mar Biol Assoc UK 48:689-733

Faulkner DJ (1999) Marine natural products. Nat Prod Rep 16: 155-198

Fortes MD, Lüning K (1980) Growth rates of North Sea macroalgae in relation to temperature, irradiance and photoperiod. Helgol Meeresunters 34:15-29

Fukuda R, Ogawa H, Nagata T, Koike I (1998) Direct determination of carbon and nitrogen contents of natural bacterial assemblages in marine environments. Appl Environ Microbiol 64:3352-3358

Gacia E, Littler MM, Littler DS (1996) The relationships between morphology and photosynthetic parameters within the polymorphic genus Caulerpa. J Exp Mar Biol Ecol 204:209-224

Geider RJ, La Roche J, Greene RM, Olaizola M (1993) Response of the photosynthetic apparatus of Phaeodactylum tricornutum (Bacillariophyceae) to nitrate, phosphate, or iron starvation. J Phycol 29:755-766

Gordillo FJL, Figueroa FL, Niell FX (2003) Photon and carbon-use efficiency in Ulva rigida at different $\mathrm{CO}_{2}$ and $\mathrm{N}$ levels. Planta 218:315-322

Grasshof K, Ehrhardt M, Kremling K (1983) Methods of seawater analysis. Verlag Chemie, Weinheim

Häder DP, Porst M, Herrmann H, Schäfer J, Santas R (1997) Photosynthesis of the Mediterranean green alga Caulerpa prolifera measured in the field under solar irradiation. J Photochem Photobiol B 37:66-73

Hanelt D (1998) Capability of dynamic photoinhibition in Arctic macroalgae is related to their depth distribution. Mar Biol 131:361-369

Hemminga MA, Duarte CM (2000) Seagrass Ecology. Cambridge University Press, Cambridge

Henley WJ, Levavasseur G, Franklin LA, Osmond CB, Ramus $\mathrm{J}$ (1991) Photoacclimation and photoinhibition in Ulva rotundata as influenced by nitrogen availability. Planta 184:235-243

Hernández I, Peralta G, Pérez-Lloréns JL, Vergara JJ, Niell FX (1997) Biomass and dynamics of growth of Ulva species in Palmones river estuary. J Phycol 33:764-772

Jacobs WP (1994) Caulerpa. Sci Am 271:66-71

Jassby AD, Platt T (1976) Mathematical formulation of the relationship between photosynthesis and light for phytoplankton. Limnol Oceanogr 21:540-547

Jaubert JM, Chisholm JRM, Minghelli-Roman A, Marchioretti M, Morrow JH, Ripley HT (2003) Re-evaluation of the extent of Caulerpa taxifolia development in the northern Mediterranean using airborne spectographic sensing. Mar Ecol Prog Ser 263:75-82

Jeffrey SW, Humphrey GF (1975) New spectrophotometric equations for determining chlorophylls $a_{1} b, c_{1}$ and $c_{2}$ in higher plants, algae and natural phytoplankton. Biochem Physiol Pflanz 167:191-194

Jousson O, Pawlowski J, Zaninetti L, Zechman FW, Dini F,
Di Guiseppe G, Woodfield R, Meinesz A (2000) Invasive alga reaches California. Nature 408:157-158

Jung V, Thibaut T, Meinesz A, Pohnert G (2002) Comparison of the wound-activated transformation of Caulerpenyne by invasive and noninvasive Caulerpa species of the Mediterranean. J Chem Ecol 28:2091-2105

Korb RE, Gerard VA (2000) Effects of concurrent low temperature and low nitrogen supply on polar and temperate seaweeds. Mar Ecol Prog Ser 198:73-82

Krause GH, Weis E (1991) Chlorophyll fluorescence and photosynthesis - the basics. Ann Rev Plant Physiol Plant Mol Biol 42:313-349

Larned ST (1998) Nitrogen- versus phosphorus-limited growth and sources of nutrients for coral reef macroalgae. Mar Biol 132:409-421

Le Gall Y, Braud JP, Kloareg B (1990) Protoplast production in Chondrus crispus gametophytes (Gigartinales, Rhodophyta). Plant Cell Rep 8:582-585

Levi B, Friedlander M (2004) Identification of two putative adhesive polypeptides in Caulerpa prolifera rhizoids using an adhesion model system. J Appl Phycol 16:1-9

Lobban CS, Harrison PJ (1997) Seaweed ecology and physiology. Cambridge University Press, Cambridge

Malta Ej, Verschuure JM (1997) Effects of environmental variables on between-year variation of Ulva growth and biomass in a eutrophic brackish lake. J Sea Res 38:71-84

Meinesz A, Benichou L, Blachier J, Komatsu T, Lemeé R, Molenaar H, Mari X (1995) Variations in the structure, morphology and biomass of Caulerpa taxifolia in the Mediterranean Sea. Bot Mar 38:499-508

Meinesz A, Belsher T, Thibaut T, Antolic B and 18 others (2001) The introduced green alga Caulerpa taxifolia continues to spread in the Mediterranean. Biol Invasions 3: 201-210

Meusnier I, Olsen JL, Stam WT, Destombe C, Valero M (2001) Phylogenetic analyses of Caulerpa taxifolia (Chlorophyta) and of its associated bacterial microflora provide clues to origin of the Mediterranean introduction. Mol Ecol 10: 931-946

Oborny B, Cain M (1997) Models of spatial spread and foraging in clonal plants. In: de Kroon $\mathrm{H}$, van Groenendael J (eds) The ecology and evolution of clonal growth in plants. Backhuys Publishers, Leiden, p 155-183

Parkhill JP, Maillet G, Cullen JJ (2001) Fluorescence-based maximal quantum yield for PSII as a diagnostic tool of nutrient stress. J Phycol 37:517-529

Paul VJ, Fenical W (1986) Chemical defense in tropical green algae, order Caulerpales. Mar Ecol Prog Ser 34:157-169

Pedersen MF, Borum J (1996) Nutrient control of algal growth in estuarine waters: nutrient limitation and the importance of nitrogen requirements and nitrogen storage among phytoplankton and species of macroalgae. Mar Ecol Prog Ser 142:261-272

Pedersen MF, Borum J (1997) Nutrient control of estuarine macroalgae: growth strategy and the balance between nitrogen requirements and uptake. Mar Ecol Prog Ser 161: 155-163

Piazzi L, Ceccherelli G, Cinelli F (2001) Threat to macroalgal diversity: effects of the introduced green alga Caulerpa racemosa in the Mediterranean. Mar Ecol Prog Ser 210: 149-159

Ralph PJ (1999) Light-induced photoinhibitory stress responses of laboratory-cultured Halophila ovalis. Bot Mar 42:11-22

Robledo D, Pelegrín YF (1997) Chemical and mineral composition of six potentially edible seaweed species of Yucatán. Bot Mar 40:301-306

Sánchez-Moyano JE, Estacio FJ, García-Adiego EM, García- 
Gómez JC (2001) Effect of the vegetative cycle of Caulerpa prolifera on the spatio-temporal variation of invertebrate macrofauna. Aquat Bot 70:163-174

Santelices B (2004) A comparison of ecological responses among aclonal (unitary), clonal and coalescing algae. J Exp Mar Biol Ecol 300:31-64

Schaffelke B, Murphy N, Uthicke S (2002) Using genetic techniques to investigate the sources of the invasive alga Caulerpa taxifolia in three new locations in Australia. Mar Pollut Bull 44:204-210

Schreiber U, Bilger W, Hormann H, Neubauer C (1999) Chlorophyll fluorescence as a diagnostic tool: basics and some aspects of practical relevance. In: Hall DO, Rao KK (eds) Photosynthesis. Cambridge University Press, Cambridge, p 321-336

Shanmugam M, Ramavat BK, Mody KH, Oza RM, Tewari A (2001) Distribution of heparinoid-active sulphated polysaccharides in some Indian marine green algae. Indian J Mar Sci 30:222-227

Short FT (1983) The seagrass Zostera marina L.: plant morphology and bed structure in relation to sediment ammonium in Izembek Lagoon, Alaska. Aquat Bot 16: 149-161

Sokal RR, Rohlf FJ (1995) Biometry. WH Freeman, New York

Terrados J, Ros J (1991) Production dynamics in a macrophyte-dominated ecosystem: the Mar Menor coastal lagoon (SE Spain). Oecol Aquat 10:255-270

Editorial responsibility: Otto Kinne (Editor-in-Chief), Oldendorf/Luhe, Germany
Terrados J, Ros J (1992) The influence of temperature on seasonal variation of Caulerpa prolifera (Forsskål) Lamouroux photosynthesis and respiration. J Exp Mar Biol Ecol 162:199-212

Terrados J, Borum J, Duarte CM, Fortes MD, Kamp-Nielsen L, Agawin N, Kenworthy WJ (1999) Nutrient and mass allocation of south-east Asian seagrasses. Aquat Bot 63: 203-217

Underwood AJ (1997) Experiments in ecology. Cambridge University Press, Cambridge

Williams SL (1984) Uptake of sediment ammonium and translocation in a green macroalga Caulerpa cupressiodes. Limnol Oceanogr 29:374-379

Williams SL, Grosholz ED (2002) Preliminary reports from the Caulerpa taxifolia invasion in southern California. Mar Ecol Prog Ser 233:307-310

Williams SL, Breda VA, Anderson TW, Nyden BB (1985) Growth and sediment disturbances of Caulerpa spp. (Chlorophyta) in a submarine canyon. Mar Ecol Prog Ser 21:275-281

Yentsch CS, Yentsch CM, Phinney DA, Lapointe BE, Yentsch SFW (2004) The odyssey of new production. J Exp Mar Biol Ecol 300:15-30

Young E, Beardall J (2003) Rapid ammonium- and nitrateinduced perturbations to chl a fluorescence in nitrogenstressed Dunaliella tertiolecta (Chlorophyta). J Phycol 39: $332-342$

Submitted: October 14, 2004; Accepted: April 21, 2005

Proofs received from author(s): July 29, 2005 